\title{
PUBLIC FINANCIAL CONTROL AS ONE OF THE MECHANISMS STATE MANAGEMENT SYSTEMS
}

\section{Latkovska T. A., Pokataiev P. S.}

\section{INTRODUCTION}

In the process of financial activity of the state, a special role is given to public financial control, through which both prevention and termination of offenses in the financial sphere are carried out. The absence of this public-law instrument can lead to destabilization of the whole sphere of financial and legal regulation.

However, public (state and local) control quite often is seen as a public financial control, without taking into account local and regional aspects of public financial control. Even in many translated publications there is a substitution of "public" for "state". Thus, in 2007, at the initiative of the European Commission to build new structures for public financial control was published a fundamental work, created by Robert de Koning named "Public Internal Financial Control (PIFC)", which is a member of the European Commission and the head of the PIFC Group ${ }^{1}$. There was a change of the named terms in translation of the work into other languages.

Today, in the process of new modernization, our country is experiencing in its development along with the global economic crisis, which causes a difficult transition period on the way of becoming a rule of law and becoming a full participant in the processes taking place in the modern civilized world.

Formation of the state system, which is unstable in crisis, stimulates both the increase of social tension and aggravation of the criminogenic situation, as well as slowing down the updating of the current legislation in the field of public financial control to improve its quality and efficiency both at the state and local level. Public financial control is one of the most important mechanisms of the government system.

\section{Public nature of social economic relations, related to finance}

In recent years the term "public" is often used to characterize various social phenomena and processes. In financial law the concepts of public finance, public funds are used: in civil law - public partnerships, public contract, public law entities, public law entity, public offering, public order, public auction, public offering; in administrative - public authority.

1 Public Internal Financial Control : http://pifc.eu/wp-content/uploads/2017/11/ 
The Law of Ukraine "On Open Use of Public Funds" ${ }^{2}$ adopted by the Verkhovna Rada of Ukraine also contains rules on public funds, stating that these are funds from the state budget, the budget of the Autonomous Republic of Crimea and local budgets, credit resources provided under state and local guarantees, funds of the National Bank of Ukraine, state banks, state trust funds, the Pension Fund of Ukraine, funds of compulsory state social insurance, as well as funds of economic entities of state and communal property received by them from their business activity.

Business entities of state and communal property - enterprises formed in due course by public authorities, authorities of the Autonomous Republic of Crimea or bodies of local self-government and are empowered to receive state funds, to take over their obligations and to make payments, including state, state-owned enterprises, communal enterprises, as well as commercial companies in which the authorized capital of the state or communal share of shares (shares, units) exceeds 50 percent, their subsidiaries, as well as enterprises, economic entities in which the authorized capital of which more than 50 percent is owned by state, including state-owned enterprises, public utilities and economic entities, in the authorized capital of which the state or communal share of shares (shares, units) exceeds 50 percent, mergers such enterprises.

Therefore, the provisions of the Law apply to relations related to the preparation and disclosure of information about the planned and actual use of public funds again.

The combination of these words and phrases, combined by the concept of "public interest", determines in modern society and the state of static and dynamics of most economic, social and political processes.

It is worth noting that only in the concept of "public interest" can the grounds be found for the expression "public law" 3 to which financial law applies. It is the public nature of public economic relations related to the sphere of finance, money and credit that largely determines their financial and legal content, that is, the regulation of financial law as a public right.

\section{Public financial control as a complex legal system}

Public financial activity in the form of control is carried out by all state bodies irrespective of the tasks that are carried out by them. However, since control does not act in isolation but is implemented in relation to a specific subject matter, the scope of control activity, forms and methods of its manifestation differ depending on the sphere or branch of state activity, as well as on the special place of the authority exercising control powers in the

${ }^{2}$ Про відкритість використання публічних коштів : Закон України від 11 лютого 2015 року № 183-VIII : Відомості Верховної Ради України. 2015. № 16. Ст.109.

${ }^{3}$ Рождественский А. Теория субъективных публичных прав. Критикосистематическое исследование. М., 1913. С. 228. 
general system. state mechanism. According to researchers, financial control is a whole set of measures aimed at creating an effective system for combating misuse of state and municipal monetary resources. Financial control can only be ensured if a system of controlling entities is well organized ${ }^{4}$.

Control involves two groups of relationships:

1) assessment of the compliance or non-compliance of a particular condition of a controlled object with the required indicators;

2) identification of errors in management activities and preparation of proposals for their correction.

Scientists distinguish the following types of control: departmental control, which is a function, part of the most inter-sectoral administrative activity of state bodies; super-agency control as a cross-sectoral inspection or state oversight of the execution of part of the functions of ministries with a complex of law enforcement powers; internal control as part of the activities of the system management body ${ }^{5}$.

In the scientific literature, financial control is distinguished depending on the time of conducting: previous, current (operational), subsequent (next); depending on the entity that exercises financial control: state ${ }^{6}$, municipal, control of financial institutions, audit; by the forms of holding: initiative and obligatory; on the focus of control actions of financial bodies: strategic and tactical.

There are also views that, depending on the relationship between the entity - the public financial activity and the entity - the controlling authority, public financial control is divided into two main types: internal and external.

In internal control, the public financial activity of each entity is controlled by the entity through special units - control departments, departments, etc. Such control takes the form of an internal audit, the purpose of which is to check the appropriateness and soundness of individual financial transactions, their compliance with the financial strategy and tactics of the entity.

External control is the audit of the public financial activity of a particular entity by the appropriate authorized inspection bodies. The purpose of this control is to verify compliance of public financial activity with the applicable financial legislation ${ }^{7}$.

4 Олексій У.О. Парламентський контроль за публічними фінансами як вид фінансового контролю. Lex Portus. 2019. 3. С. 59-68.

5 Пронина В.С. Конституционный статус органов межотраслевого правления. M., 1984. C. 104.

${ }^{6}$ Гнатовська А.І. Державний контроль як правовий механізм забезпечення сталого розвитку України. Правові та інституційні механізми забезпечення сталого розвитку України : матеріали міжнар. наук.-практ. конф. (м. Одеса, 15-16 травня 2015 р.). О. : Юридична література, 2015. С. 103-105.

${ }^{7}$ https://pidruchniki.com/1415082352601/finansi/vidi_finansovogo_kontrolyu. 
Public financial control is a complex legal system that includes many interrelated elements. One such element is the system of bodies that exercise control at the state level. It is through the analysis of the legal regulation of their financial control activities that we can conclude on the quality of legal regulation of public financial control.

\section{Approximation of activities of public financial control bodies to European standards}

Nowadays, there are a large number of supervisory authorities in Ukraine that are empowered to audit the activities of different entities. Prior to the adoption of the Tax Code, the concept of "controlling authority" could be seen in many legal acts.

Thus, in accordance with the Instruction on the Procedure for the Application of Penalty (Financial) Sanctions, the controlling body was regarded as a body of the state tax service, which, within the limits of its competence, determined by the law, controls the timeliness, reliability, completeness of accrual of taxes, fees, other obligatory payments and repayment of tax liabilities or tax debt, compliance with the Law of Ukraine "On the application of registrars of settlement transactions in the sphere of settlement of public catering and services", laws on foreign economic activity and other normative legal acts, the control of which is vested in the bodies of the state tax service ${ }^{8}$. With the adoption of the Tax Code, the said Instruction ceased to be valid on the basis of the Order of the State Tax Administration of Ukraine dated December 22, 2010 №. 982. It was considered a controlling body and as a state body which, within the limits of its competence determined by the legislation, controls the timeliness, reliability, completeness and accrual fees (mandatory payments) and repayment of tax liabilities or tax debt (STA of Ukraine Order "On Approval of the Procedure of Submission by the State Tax Service of Ukraine tax requirements to taxpayers" ${ }^{\text {) }}$.

A similar definition was provided in the STA Order "On Approval of the Procedure for Application of Administrative Arrest of Taxpayer Assets" ${ }^{10}$.

The resolution of the National Bank of Ukraine considered this body somewhat differently, namely: the controlling body is the body in which the license holder is registered ${ }^{11}$.

${ }^{8}$ Інструкція про порядок застосування штрафних (фінансових) санкцій органами державної податкової служби: Наказ ДПА України від 17.03.2001 № 110.

${ }^{9}$ Порядок направлення органами державної податкової служби України податкових вимог платникам податків: Наказ ДПА України від 03.07.2001 № 266.

10 Порядок застосування адміністративного арешту активів платників податків: Наказ ДПА від 25.09.2001 № 386.

11 Положення про порядок видачі Національним банком України індивідуальних ліцензій на використання іноземної валюти на території України як засобу платежу: Постанова Національного банку України від 14.10.2004 № 483. 
The Law of Ukraine "On the procedure for repayment of taxpayers' obligations to budgets and state trust funds" ${ }^{12}$ referred to controlling bodies: customs authorities, bodies of the Pension Fund, bodies of compulsory state social insurance funds, tax authorities.

With the adoption of the Tax Code, the powers and functions of the controlling bodies have changed and are now defined by the Tax Code, the Customs Code and the laws of Ukraine, and Article 41 of the Tax Code "Controlling and Recovery Bodies" establishes that the controlling body is the central body of executive power, which implements state tax, state customs policy, state policy on administration of the single contribution, state policy in the field of anti-law enforcement. and customs, single payment and other legislation, the control of which is vested in the controlling body, its territorial bodies $^{13}$. Moreover, the collection authorities are the sole supervisory authorities, authorized to take measures to ensure the repayment of tax debt and arrears of payment of a single contribution within the powers, as well as state executors within the limits of their powers.

The differentiation of powers and functional responsibilities of the controlling bodies is determined by the legislation of Ukraine. Moreover, other state bodies have no right to check the timeliness, accuracy, completeness of accrual and payment of taxes and fees, including at the request of law enforcement agencies.

The Law of Ukraine "On Amendments to the Tax Code of Ukraine on Improving the Investment Climate in Ukraine” ${ }^{14}$ introduced an electronic payer cabinet that will give taxpayers the opportunity to work remotely in a real-time manner, such as:

- file declarations using an electronic digital signature and review the filed and / or generated tax reports;

- to be reminded about deadlines for reporting and payment of taxes, fees (mandatory payments);

- to receive information about personal registration data (taxpayer's tax number, name of the taxpayer, main activity; P.I.B. Accountant and Director, etc.);

- to file and receive in electronic form a certificate on the absence of arrears of taxes, fees, payments controlled by the bodies of the fiscal service;

- to keep an electronic account of the Book of accounting of income and expenses;

${ }^{12}$ Про порядок погашення зобов'язань платників податків перед бюджетами та державними цільовими фондами : Закон України від 21 грудня 2000 року № 2181-III.

${ }^{13}$ Податковий кодекс від 2 грудня 2010 року № 2755-VI. Відомості Верховної Ради Украӥни. 2011 № 13-14 № 15-16. № 17. Ст. 112.

14 Про внесення змін до Податкового кодексу України щодо покращення інвестиційного клімату в Україні. Закон України від 21 грудня 2016 р. № 1797-VIII. Відомості Верховної Ради України. 2017. № 5-6. Ст. 48. 
- to review information about the state of their payments with the budget, in particular, about tax arrears, fees, a single contribution to compulsory state social insurance ${ }^{15}$.

E-cabinet is an electronic system of relations between taxpayers and state, including controllers, bodies for the exercise of their rights and obligations, envisaged by the Tax Code, consisting of:

hardware and software complex;

a portal solution for taxpayer users who work online (via the Internet in real time) and do not require the specialized use of a specialized client application;

portal solution for users - state, including supervisory, bodies;

software interface (API), which allows to realize the full functionality of e-cabinet;

other means of information, telecommunication, information and telecommunication systems.

That is, the payer's e-cabinet is a personal, automated workplace for a taxpayer who accesses work from any computer connected to the Internet by authenticating with an electronic digital signature and authorizing such a payer.

The order of functioning of the electronic cabinet is determined by the central body of executive power, which ensures the formation and implementation of the state financial policy.

The provisions of the Tax Code stipulate that the e-cabinet is created and operates according to the following principles:

transparency - the mandatory publication of a methodology for implementing the provisions of this Code in the work of the electronic cabinet;

controllability - ensuring the ability to independently verify the correctness of the electronic cabinet through a test payer (s) on an emulator created on the website of the electronic cabinet methodology for the absence of software errors, prevent unauthorized interference with the work of electronic cabinet software, which means these the authenticity of the source code;

integrations with systems used by taxpayers - open, freely available APIs for Electronic Data Interchange (EDI);

timeliness of technical and / or methodological errors elimination ensuring that the registry of technical and / or methodological errors detected by taxpayers, technical administrators and / or methodologists of the electronic cabinet is published on the official website of the electronic cabinet, determining the level of criticality of such errors and setting deadlines for such errors their elimination, informing all users of e-cabinet about the fact of detection of technical and / or methodological error, as well as about the fact of its elimination and restoration spare electronic office work in full;

\footnotetext{
${ }^{15}$ http://ch.sfs.gov.ua/media-ark/local-news/print-168670.html.
} 
automation - maximum automation of the processes of creation, acceptance, processing, storage of documents, processing and display of data (indicators) of documents and other taxpayer credentials;

completeness of functionality - the availability of such an electronic service interface that enables the exercise of the rights and obligations of the taxpayer, the receipt of documents provided for by law, and information concerning such taxpayer, online (via the Internet in real time) or through the program interface (ARI), by other means of information, telecommunication, information and telecommunication systems;

simplification of the procedure of interaction between taxpayers and the controlling body and acceleration of electronic document flow between them;

automatic logging of all activities (events) occurring in the e-cabinet, including, inter alia, fixing the date and time of departure, receipt of documents through the e-cabinet and any modification of the data available in the e-cabinet by electronic timestamp. Information on the date and time of sending and receiving documents, other correspondence with the identification of the sender and the recipient is stored indefinitely and can be obtained through the electronic office in the form of an electronic document, including in the form of a receipt in text format;

prohibition of interference, creation of restrictions on functioning and / or possibilities for use by taxpayers of e-cabinet taxes stipulated by the Tax Code;

priority of documents coming from state, including controlling, bodies, getting started in the electronic cabinet with automatic opening of messages coming from state bodies, and / or blocking the possibility of sending documents by the taxpayer until the taxpayer received documents his e-cabinet from government agencies.

Legislation empowers control bodies to carry out chamber, documentary (planned or unplanned; on-site or off-site) and factual inspections. At the same time, chamber and documentary checks are carried out by the control bodies within the limits of their powers only in cases and in the order established by the Tax Code, and actual checks - by both the Tax Code and other laws of Ukraine, the control of which is vested in the control bodies.

Commercial under the law is considered to be a check, which is carried out at the premises of the controlling body solely on the basis of the data specified in the taxpayer's tax returns (calculations) and data of the electronic system of value added tax administration (data of the central executive body implementing state policy in the field of treasury servicing of budgetary funds, which open the accounts of payers in the electronic system of value added tax administration, data of the Unified register of tax invoices and data of customs declarations), as well as data from the Unified Register of Excise Invoices and data from the electronic administration of fuel sales. 
The subject of a camera check may also be the timeliness of filing tax returns (calculations) and / or the timely registration of tax invoices and / or adjustments to tax invoices in the Unified Register of tax invoices, excise invoices and / or excise tax adjustments, correction of errors in tax invoices and / or timely payment of the agreed amount of tax (monetary) liability solely on the basis of stored data (processing The relevant information bases.

A documentary check is a check, the subject of which is timeliness, reliability, completeness of calculation and payment of all taxes and fees stipulated by the Tax Code, as well as compliance with currency and other legislation, the control of which is vested in the supervisory authorities, the employer compliance with the law on the conclusion of an employment contract, registration of labor relations with employees (employees) and conducted on the basis of tax declarations (calculations), financial reporting, tax and accounting registers required by law, primary documents used in accounting and tax accounting and related to the accrual and payment of taxes and fees, compliance with the requirements of other legislation, the control of compliance with which is vested in the controlling bodies, and received in accordance with the procedure by the controlling body of documents and tax information, including the results of audits of other taxpayers.

It should be noted that the documentary scheduled audit is carried out in accordance with the audit schedule. With regard to documentary unscheduled verification, such verification is not foreseen in the plan of work of the supervisory authority and is carried out if there is at least one of the grounds specified in the Tax Code.

A documented field visit is a check that is carried out at the location of the taxpayer or the location of the property in respect of which such a check is carried out, and a documentary non-departure check is a check carried out at the premises of the controlling body.

With regard to actual verification, it is an audit carried out at the place where the taxpayer actually conducts business, the location of economic or other objects of ownership of such payer.

Such inspection is carried out by the controlling body on compliance with the rules of the legislation on the regulation of cash circulation, the procedure for payment by taxpayers of settlement transactions, conducting cash transactions, the presence of licenses, certificates, including the production and circulation of excisable goods, compliance with the employer in compliance with the legislation on the registration of labor legislation labor relations with employees (by hired persons).

The camera inspection shall be conducted by the officials of the supervisory body without any special decision of the head (his deputy or authorized person) of such body or its direction. All tax reports are subject to a 
full-blown audit. The consent of the taxpayer to be audited and to be present during the on-the-spot check is optional.

All tax reports are subject to a full-blown audit. The consent of the taxpayer to be audited and to be present during the on-the-spot check is optional.

It should be noted that since January 2018, there has been a moratorium on inspections. It was forbidden to carry out routine inspections by control bodies for two months, and was carried out only in exceptional cases. This prohibition was contained in the Law of Ukraine "On Temporary Features of Implementing State Supervision (Control) Measures in the Field of Economic Activity" ${ }^{16}$.

The Cabinet of Ministers Resolution "On Approving the List of State Supervision (Control) Bodies Not Applicable to the Law of Ukraine "On Temporary Specific Features of Implementing State Supervision (Control) Measures in the Field of Economic Activity" approved the list of state supervisory bodies (control) that are not covered by the $\mathrm{Law}^{17}$. The moratorium was extended, in fact three groups of bodies with different levels of inspection rights were actually allocated.

The first group includes bodies to which the rules of the above law did not apply, and thus the moratorium on inspections had nothing to do with them: National Bank of Ukraine, Customs of the State Fiscal Service, State Service of Export Control of Ukraine, State Audit Service of Ukraine, Antimonopoly Committee of Ukraine, National Council of Ukraine for Television and Radio Broadcasting, Market Oversight Bodies.

The second group includes bodies authorized by the Cabinet of Ministers of Ukraine to carry out inspections.

The Cabinet of Ministers Resolution "On Approving the List of State Supervision (Control) Bodies Not Applicable to the Law of Ukraine". On Temporal Features of Implementing State Supervision (Control) Measures in the Field of Economic Activity" determined the list of bodies not subject to the moratorium. those bodies that are completely removed from the moratorium on inspections. This is, for example, the State Geocadastre, which controls in the agro-industrial complex compliance with land legislation, use and protection of land of all categories and forms of ownership, compliance with the requirements for soil fertility.

${ }^{16}$ Про тимчасові особливості здійснення заходів державного нагляду (контролю) у сфері господарської діяльності : Закон України від 3 листопада 2016 року № 1728-VIII : Відомості Верховної Ради. 2017. № 4. Ст. 37.

17 Про затвердження переліку органів державного нагляду (контролю), на які не поширюється дія Закону України «Про тимчасові особливості здійснення заходів державного нагляду (контролю) у сфері господарської діяльності» : Постанова Кабінету Міністрів України від 18.12.2017 р. № 1104. 
There are also bodies in this Ordinance which have been removed from the moratorium only in part of their powers. Thus, the State Inspectorate allowed to monitor only compliance with the requirements of the legislation on environmental and radiation safety.

The list of bodies withdrawn from the moratorium includes bodies that carry out unscheduled inspections only on the grounds specified by Law № 877, and there are those who are guided by their respective profile laws.

And the third group is under the moratorium, that is, all other inspections that remained under the moratorium until the end of 2018.

Therefore, a moratorium on these bodies meant that the law prohibited in 2018 from carrying out routine inspections of all businesses and individuals. Instead, the legislation provided for six grounds for unscheduled inspections, including: a complaint by an individual (if the State Regulatory Service of Ukraine approves such inspection); desires of the enterprise; judgment; accident, death of the victim as a result of an accident (if related to the activity of the enterprise); an event that has a significant adverse effect on the person, environment and security of the state.

So far no one knows what these events are, because the criteria for determining negative impact were set by the Cabinet of Ministers of Ukraine; Verification of the fulfillment of the prescription made on the results of the preliminary verification.

The Explanatory Note to the Draft Law of Ukraine "On the Fundamental Principles of Public Financial Control Bodies" states that in the current context, the issues of effectiveness of the instruments of the Cabinet of Ministers of Ukraine, which it uses to create the basis and incentives for carrying out reforms and developing a strong and effective system, are of particular relevance. management of public finances, in particular public financial control as an indispensable condition for sustainable socioeconomic growth ${ }^{18}$.

Considering that the current state of socio-economic development of the Ukrainian state is characterized, on the one hand, by the dynamism and multi-vectority of development processes and reforms in all spheres of public life in general and public administration in particular, which are conditioned primarily by its European integration aspirations, and secondly, the complexity of the implementation of national goals and objectives in different spheres of public life due to a number of factors, including the limited amount of necessary financial resources in the state, the imperfection and inconsistency of the legislative framework, the low level of interaction of state bodies between themselves and society, it is necessary to build an effective

\footnotetext{
${ }^{18}$ Пояснювальна записка до проекту Закону України «Про основні засади діяльності органів державного фінансового контролю» від 17.09.2018 № 9086: http://search.ligazakon.ua/__doc2.nsf/link1/GH70E00A.html.
} 
mechanism for managing to increase the level of internal control and audit in public authorities, to increase the extremely low level of financial and budgetary discipline.

The State Audit Office is a special body of financial control in Ukraine, which within the limits of the existing right-hand field on behalf of the Cabinet of Ministers of Ukraine forms and implements state policy in the sphere of financial control ${ }^{19}$.

The quality of the public financial control function through the implementation of state financial audits, audit and monitoring of procurement and inspection (audits) depends on the quality of the legal, organizational and methodological, information support of the State Audit Service and its interregional territorial bodies.

Part 2 of Article 19 of the Constitution of Ukraine ${ }^{20}$ stipulates that state authorities and local self-government bodies, their officials are obliged to act only on the basis, within the powers and in the manner provided by the Constitution and laws of Ukraine. It should be noted that control over the implementation of local budgets is also a type of public financial control ${ }^{21}$.

At the same time, paragraph 12 of part one of Article 92 of the Constitution of Ukraine stipulates, in particular, that the organization and activities of executive bodies are determined solely by the laws of Ukraine.

In addition, part two of Article 120 of the Constitution of Ukraine stipulates that the organization, powers and procedure of activity of the Cabinet of Ministers of Ukraine, other central and local bodies of executive power are determined by the Constitution and laws of Ukraine.

According to the second part of Article 3 of the Law of Ukraine "On Central Bodies of Executive Power" ${ }^{22}$, the organization, powers and order of activity of ministries, other central executive bodies are determined by the Constitution of Ukraine, this and other laws of Ukraine.

In turn, pursuant to Article 116, paragraphs 5, 6, 9 and 91, of the Constitution of Ukraine, the Cabinet of Ministers of Ukraine, in particular, ensures equal conditions for the development of all forms of ownership; manages state property objects in accordance with the law; ensures implementation of the State Budget of Ukraine approved by the Verkhovna Rada of Ukraine; directs and coordinates the work of ministries, other

19 Положення про Державну аудиторську службу України: Постанова Кабінету Міністрів України від 3 лютого 2016 р. № 43 : http://zakon.rada.gov.ua/laws/show/43-2016-п.

${ }_{20}$ Конституція України, прийнятана пятій сесії Верховної Ради України 28 червня 1996 року : Відомості Верховної Ради Украӥни. 1996. № 30. Ст. 141.

${ }^{21}$ Марущак А.В. Правові основи контролю за виконанням місцевих бюджетів. Legal practice in EU and Ukraine at the modern stage. Arad, Romania, 25-26 January, 2019. P. 393-395.

22 Про центральні органи виконавчої влади : Закон України від 17 березня 2011 року № 3166-VI : Відомості Верховної Ради Украӥни. 2011. № 38. Ст. 385. 
executive bodies, and creates, reorganizes and liquidates ministries and other central executive bodies in accordance with the law, acting within the limits of the funds provided for the maintenance of executive bodies.

Also, in accordance with part eight of Article 21 of the Law of Ukraine "On the Cabinet of Ministers of Ukraine" ${ }^{23}$, the peculiarities of the relations of the Cabinet of Ministers of Ukraine with individual central executive bodies may be determined by the laws of Ukraine.

According to part four of Article 24 of the Law of Ukraine "On Central Executive Bodies", the provisions of this Law shall be extended to the Antimonopoly Committee of Ukraine, the State Property Fund of Ukraine, the State Committee for Television and Radio Broadcasting of Ukraine, and other central executive bodies with the special status of the Cabinet of Ministers with special status cases where the Constitution and laws of Ukraine define other features of the organization and the order of their activity.

Therefore, for the creation and development of consolidated and harmonized legislation with effective mechanisms for its implementation in the field of public financial control, which is the focus of strategic reforms of the state development in the medium term, a draft Law of Ukraine "On the Fundamental Principles of Public Financial Control Bodies” was drafted. development of modern and effective legislation in the field of public financial control. We believe that this bill should be called the Law of Ukraine "On the Fundamental Principles of Public Financial Control Bodies”.

The need to develop the project is based on such strategic documents as the Government's Mid-Term Priority Action Plan for 2020 and the Government's Priority Action Plan for 2017, approved by the Decree of the Cabinet of Ministers of Ukraine of April 3, 2017 No. 275; Strategy for reform of the public finance management system for 2017-2020, approved by the Decree of the Cabinet of Ministers of Ukraine dated February 08, 2017 № 142; Ukraine 2020 Strategy for Sustainable Development, approved by Presidential Decree \# 5 of January 12, 2015, reflects the ways of resolving problematic and unresolved issues in the area of public financial control, implementation of the European Union's aspirations of the Cabinet of Ministers and the country, as well as approximation to the European principles of functioning of the bodies of financial control. We believe that the introduction of new reforms in the field of public financial control requires the need to introduce new forms of interaction between the subjects of financial legal relations, reforming both the financial and its component - the tax

${ }^{23}$ Про Кабінет Міністрів України : Закон України від 27 лютого 2014 року № 794-VII : Відомості Верховної Ради України. 2014. № 13. Ст. 222. 
system as a whole, changes in the relationship between business and regulatory bodies ${ }^{24}$.

It is especially important to pay attention today to the weaknesses of public administration, both in general in the economy and directly in the financial sphere, which is reflected in the inconsistency and inefficiency of public policy regarding the systematic organization of public financial control. The low efficiency of such control is explained by the lack of a generalized legal model and a unified approach to understanding the directions of its further development, which does not allow to fully improve the current legislation in this field.

\section{CONCLUSIONS}

Thus, to summarize, it can be concluded that public financial control is one of the constituent forms and parts of a single integrated control system, which is to regulate and verify the legality and effectiveness of actions (actions and omissions) associated with the creation, distribution and the use of material resources to disclose deviations from established standards, principles, and legal requirements at an earlier stage.

Therefore, it is important to qualitatively enhance functions and build a coherent, effective and efficient system of public financial control; create an effective institutional framework for the activities of public financial control bodies; to provide the conceptual framework for the development of the legal and methodological framework for the operation of public financial control and the activities of public financial control bodies, in line with the best practices of the European Union, to promote fiscal discipline and minimize abuse in public finance. It is important to create a transparent system of public administration and use of financial resources that will enhance public confidence in government bodies.

Today particular attention needs to be given to defining the main purpose and role in the implementation of the public financial policy of public financial control bodies.

Public financial control is an important component of a democratic state's financial system, as it ensures that public financial management processes are appropriate to the needs of society. The independence and comprehensiveness of such controls are prerequisites for its effective implementation. Public financial control should be considered as a purposeful activity of authorized state bodies, local self-government bodies, enterprises,

24 Латковська Т.А. Перспективи перетворення Державної фіскальної служби 3 контролюючого органу на сервісну службу. Правові та інституційні механізми забезпечення розвитку держави та права в умовах євроінтеграції : матеріали Міжнар. наук.практ. конф. (20 травня 2016 р., м. Одеса) у 2 т. Т. 2 / відп. ред. М.В. Афанасьєва. Одеса : Юридична література, 2016. С. 64-66. 
institutions, organizations, public associations regulated by legal norms irrespective of forms of ownership and other entities that exercise public interest in the process of public compliance with the law financial activities.

The underestimation of the role of public financial control is one of the causes of the crisis in our country in recent years, the existence of an objective need to create an effective, efficient and viable financial system and, as a consequence, improve the level of financial discipline that will reduce the number of budget- financial violations, gives rise to the need to pay attention to the resolution of problematic issues in the sphere of functioning of the system of state financial control in Ukraine.

Today, based on world experience, Ukraine is moving from retrospective forms of state control, such as audits and audits, to its new form, the state financial audit.

\section{SUMMARY}

In the process of financial activity of the state a special role is assigned to public financial control, through which both the prevention and the termination of offenses in the financial sphere are carried out. The absence of this public-law instrument can lead to destabilization of the whole sphere of financial and legal regulation. Public financial control is a fairly complex legal system, which includes numerous interconnected elements. One such element is the system of bodies that exercise control at the state level. It is through the analysis of legal regulation of their financial and control activities that we can conclude that the quality of legal regulation of public financial control. It is especially important today to draw attention to the fact that there are weaknesses in public administration both in general in the economy and directly in the financial sphere, which is expressed in the inconsistency and ineffectiveness of the state policy regarding the systemic organization of public financial control, whose low effectiveness is explained by the lack of a generalized legal model and the only approach to understanding the directions of its further development, which does not allow to perfectly improve the current legislation in this area.

\section{REFERENCES}

1. Public Internal Financial Control : http://pifc.eu/wp-content/uploads/ 2017/11/Pifc-Russian.pdf.

2. Про відкритість використання публічних коштів : Закон України від 11 лютого 2015 року № 183-VIII : Відомості Верховної Ради України. 2015. № 16. Ст. 109.

3. Рождественский А. Теория субъективных публичных прав. Критико-систематическое исследование. М., 1913. С. 228. 
4. Олексій У.О. Парламентський контроль за публічними фінансами як вид фінансового контролю. Lex Portus. 2019. 3. С. 59-68.

5. Пронина В.С. Конституционный статус органов межотраслевого правления. М., 1984. С. 104.

6. Гнатовська А.І. Державний контроль як правовий механізм забезпечення сталого розвитку України. Правові та інституційні механізми забезпечення сталого розвитку України : матеріали міжнар. наук.-практ. конф. (м. Одеса, 15 - 16 травня 2015 р.). О. : Юридична література, 2015. С. 103-105. kontrolyu.

7. https://pidruchniki.com/1415082352601/finansi/vidi_finansovogo_

8. Інструкція про порядок застосування штрафних (фінансових) санкцій органами державної податкової служби: Наказ ДПА України від 17.03.2001 № 110 .

9. Порядок направлення органами державної податкової служби України податкових вимог платникам податків: Наказ ДПА України від 03.07.2001 № 266.

10. Порядок застосування адміністративного арешту активів платників податків: Наказ ДПА від 25.09.2001 № 386.

11. Положення про порядок видачі Національним банком України індивідуальних ліцензій на використання іноземної валюти на території України як засобу платежу: Постанова Національного банку України від 14.10.2004 № 483.

12. Про порядок погашення зобов'язань платників податків перед бюджетами та державними цільовими фондами : Закон України від 21 грудня 2000 року № 2181-III.

13. Податковий кодекс від 2 грудня 2010 року № 2755-VI. Відомості Верховної Ради України. 2011 № 13-14 № 15-16. № 17. Ст. 112.

14. Про внесення змін до Податкового кодексу України щодо покращення інвестиційного клімату в Україні. Закон України від 21 грудня 2016 р. № 1797-VIII. Відомості Верховної Ради України. 2017. № 5-6. Ст. 48.

15. Що таке «електронний кабінет платника»? Офіційний портал Державної фіскальної служби України. http://ch.sfs.gov.ua/media-ark/ local-news/print-168670.html.

16. Про тимчасові особливості здійснення заходів державного нагляду (контролю) у сфері господарської діяльності : Закон України від 3 листопада 2016 року № 1728-VIII : Відомості Верховної Ради. 2017. № 4 . Ст. 37.

17. Про затвердження переліку органів державного нагляду (контролю), на які не поширюється дія Закону України «Про тимчасові особливості здійснення заходів державного нагляду (контролю) у сфері 
господарської діяльності» : Постанова Кабінету Міністрів України від 18.12.2017 р. № 1104 .

18. Пояснювальна записка до проекту Закону України «Про основні засади діяльності органів державного фінансового контролю» від 17.09.2018 № 9086: http://search.ligazakon.ua/1_doc2.nsf/link1/ GH70E00A.html.

19. Положення про Державну аудиторську службу України: Постанова Кабінету Міністрів України від 3 лютого 2016 р. № 43 : http://zakon.rada.gov.ua/laws/show/43-2016-п.

20. Конституція України, прийнята на пятій сесії Верховної Ради України 28 червня 1996 року : Відомості Верховної Ради України. 1996. № 30. Ст. 141.

21. Марущак А.В. Правові основи контролю за виконанням місцевих бюджетів. Legal practice in EU and Ukraine at the modern stage. Arad, Romania, 25-26 January, 2019. P. 393-395.

22. Про центральні органи виконавчої влади : Закон України від 17 березня 2011 року № 3166-VI : Відомості Верховної Ради України. 2011. № 38. Ст. 385.

23. Про Кабінет Міністрів України : Закон України від 27 лютого 2014 року № 794-VII : Відомості Верховної Ради України. 2014. № 13. Ст. 222.

24. Латковська Т.А. Перспективи перетворення Державної фіскальної служби з контролюючого органу на сервісну службу. Правові та інституційні механізми забезпечення розвитку держави та права в умовах євроінтеграції : матеріали Міжнар. наук.-практ. конф. (20 травня 2016 р., м. Одеса) у 2 т. Т. 2 / відп. ред. М.В. Афанасьєва. Одеса : Юридична література, 2016. С. 64-66.

25. Савченко Л.А. Фінансово-контрольне право: становлення та розвиток : монографія. К.: Юрінком Інтер, 2017. 400 с.

\section{Information about the author:} Latkovska T. A.,

Doctor of Juridical Sciences, Professor, Chernivtsi Law Institute, National University “Odessa Law Academy” 7, Skovorody str., Chernivtsi, 58000, Ukraine ORCID ID: 0000-0003-3159-5994

Pokataiev P. S., Doctor of Law, Doctor of Sciences of the State Administration, Professor, First Vice-Rector,

Classic Private University 70b, Zhukovskoho str., Zaporizhia, 69002, Ukraine ORCID ID: 0000-0003-3806-2197 